Gomez et al., Afr J Tradit Complement Altern Med. (2016) 13(4):55-59

doi: 10.21010/ajtcam.v13i4.9

\title{
ANTIMICROBIAL ACTIVITY OF GYMNOSPERMA GLUTINOSUM (SPRENG.) LESS. (ASTERACEAE) METHANOL EXTRACTS AGAINST HELICOBACTER PYLORI
}

\author{
Ricardo Gomez-Flores*1, David Espinosa-Ramos ${ }^{1}$, Ramiro Quintanilla-Licea ${ }^{2}$, María Porfiria Barrón- \\ Gonzalez $^{3}$, Patricia Tamez-Guerra ${ }^{1}$, Reyes Tamez-Guerra ${ }^{1}$, Cristina Rodriguez-Padilla ${ }^{1}$
}

${ }^{1}$ Universidad Autónoma de Nuevo León, Facultad de Ciencias Biológicas, Departamento de Microbiología e Inmunología, ${ }^{1}$ Departamento de Química, ${ }^{2}$ Departamento de Biología Celular y Genética, ${ }^{3}$ San Nicolás de los Garza, NL. México.

*Corresponding author: Ricardo Gomez-Flores, E-mail: rgomez60@ hotmail.com

\begin{abstract}
Background: Prolonged use of antibiotics may lead to the selection of drug-resistant bacteria; as a result, efforts are being made to identify new and effective antimicrobial agents, particularly, from medicinal plants, against bacterial infections. Antimicrobial activity of Gymnosperma glutinosum against Helicobacter pylori has not yet been reported.

Materials and methods: The antibacterial in vitro effect of Gymnosperma glutinosum methanol leaf extracts against Helicobacter pylori (ATCC 43504) was evaluated in liquid medium by the colorimetric 3-[4,5-dimethylthiazol-2-yl]-2,5-diphenyltetrazolium bromide (MTT) reduction assay and in solid medium by the colony forming units (CFU) method.

Results: Methanol extracts significantly $(p<0.05)$ inhibited in vitro $H$. pylori growth in liquid medium from $24 \%$ to $82 \%$ at concentrations ranging from $31.25 \mathrm{mg} / \mathrm{ml}$ to $500 \mathrm{mg} / \mathrm{ml}$, respectively, and in solid medium the extracts caused significant $(p<0.05) 52 \%$ and $100 \%$ bacterial growth inhibition at concentrations of $250 \mu \mathrm{g} / \mathrm{mL}$ and $500 \mu \mathrm{g} / \mathrm{mL}$, respectively, as compared with untreated control. Methanol vehicle did not affect $H$. pylori growth.

Conclusion: The observed antibacterial effect of G. glutinosum extracts may be of benefit as an adjuvant treatment of diseases caused by H. pylori.
\end{abstract}

Key words: Gymnosperma glutinosum, Helicobacter pylori, methanol extract, minimal inhibitory concentration (MIC).

\section{Introduction}

Helicobacter pylori (H. pylori) is a Gram-negative spiral-shaped bacteria, which is the main factor for the development of duodenal ulcer disease and has been involved in the development of gastric ulcer, which increases the risk of stomach cancer, the most common digestive tract neoplasia worldwide (Arana y Corona, 2009). In developed countries, 70 to $90 \%$ of the population becomes infected before 10 years of age and the modes of transmission include oral-oral or fecal-oral, and iatrogenic when performing endoscopy with a contaminated tube from person to person (Dunn et al., 1997). In addition to surgery, including partial gastrectomy, a variety of antibiotics approved by the United States Food and Drug Administration to treat gastric ulcer have been suggested, among which it is common the use of bismuth subsalicylate, metronidazole, and tetracycline, in addition to an antacid agent; however, this can cause systemic damage such as pseudo-membranous colitis (11\%) and vaginal candidiasis (above 10\%) in women under treatment (Dunn et al., 1997).

H. pylori infections are currently treated with antibiotics, plant extracts, and various types of immunization with the aim of preventing the colonization of the bacterium, as well as eradicate it when it is established in gastric epithelial cells. Different antibiotics have been suggested to treat $H$. pylori; among these, the use of 10 to 14 days of $20 \mathrm{mg}$ omeprazole twice daily or using plus amoxicillin 1g, 2 times per day, can remove 80 to $90 \%$ of these bacteria (Ramakrishnan et al., 2007). An antibiotic scheme 7 days in patients infected with $\mathrm{H}$. pylori on the basis of $400 \mathrm{mg}$ of ranitidine, metronidazole $500 \mathrm{mg}$, and $500 \mathrm{mg}$ of clarithromycin was used before meals in another study, in which they found elimination of the bacteria in $91 \%$ of 47 patients (Hoffman et al., 1999).

There is a general warning about the potential benefits of medicinal plants for health, as part of complementary medicine in the world (Gomez-Flores et al., 2010, 2009). Plants play a vital role in the medicinal practices of many Native Americans who use them not only for diagnosis and treatment, such as Ginseng (Panax quinquefolius, Panax ginseng, Eleutherococcus senticosus), Echinacea (Echinacea purpurea, Echinacea angustifolia, Echinacea pallida), and Goldenseal (Hydrastis canadensis), but also to enhance immune responses against many diseases (Borchers et al., 2000). Interest in botanical medicine has increased over the years, not only by physicians, but also by public in general who seem to prefer natural products than synthetic ones (Borchers et al., 2000; Torrado-Truiti et al., 2003). Although there are a great number of plants in Mexico, the percent of species studied for their antimicrobial activity is low, and their effectiveness must be scientifically validated to increase the credibility of their use (Garcia-Alvarado et al., 2001). Some plant 


\section{Gomez et al., Afr J Tradit Complement Altern Med. (2016) 13(4):55-59}

\section{doi: 10.21010/ajtcam.v13i4.9}

families have been demonstrated to produce antimicrobial substances against a wide variety of bacteria (Akihisa et al., 2005) and fungus (Stein et al., 2006).

Gymnosperma glutinosum is a gummy shrub, 1-1.5 m high, distributed from Guatemala and Mexico to the southeastern United States. In traditional medicine in Mexico, this plant (known as tatalencho, ladybug, motita, jarilla, fox tail, xonequitl, sticky grass, among other names) is used for the treatment of diarrhea, ulcers, pain, and rheumatism (Martinez, 1989). The few phytochemical studies to date have resulted in the discovery of more than 20 flavonoids (Dominguez and Torre, 1974) from the alcoholic extracts and 4 diterpenes (Maldonado et al., 1994; Calderon et al., 2001) of the hexane extracts. Serrano et al. (2009) reported antifungal activity of an ent-labdane type diterpene from G. glutinosum, whereas Quintanilla-Licea et al. (2012) found antitumor activity of compounds hentriacontane (1) and $(+)-13 \mathrm{~S}, 14 \mathrm{R}, 15$-trihydroxy-ent-labd-7-ene, as well as the ent-labdane diterpene (-)-13S,14R,15-trihydroxy-7-oxo-ent-labd-8(9)-ene from this plant. Furthermore, G. glutinosum has been reported to possess antibiotic activity against Sarcina lutea, Aspergillus niger, and Trichophyton mentagrophytes (Canales et al., 2007), Mycobacterium tuberculosis (Gomez-Flores et al., 2008). Canales et al. (2004) reported that G. glutinosum extracts possessed antibacterial activity against Staphylococcus aureus, Staphylococcus epidermidis, Vibrio cholera and Shigell aboydii.

The present study was designed to evaluate the effects of the Gymnosperma glutinosum leaf extracts on $H$. pylori growth. The plant belongs to the family Asteraceae, but has not been previously reported to have antimicrobial activity against this bacterium. We found significant in vitro growth inhibition activity of $G$. glutinosum extracts against $H$. pylori.

\section{Material and Methods}

Reagents, culture medium, and bacterial strain

Brucella broth was obtained from Difco (Detroit MI), 3-[4,5-dimethylthiazol-2-yl]-2,5-diphenyltetrazolium bromide (MTT) was purchased from Sigma-Aldrich (St. Louis, MO), and dimethyl sulfoxide (DMSO) was obtained from Amresco (Solon, OH). $H$. pylori ATCC 43504 was donated by the Laboratorio de Odontología from Centro de Investigación y Desarrollo en Ciencias de la Salud at Universidad Autónoma de Nuevo León, México, and maintained in Brucella broth (Difco, Detroit, MI).

\section{Plant extract preparation}

Gymnosperma glutinosum (Spreng.) Less. was collected in Escobedo, NL, México and identified by Biol. Ma. del Consuelo González from Facultad de Ciencias Biológicas Herbarium at Universidad Autónoma de Nuevo León, México, with the specimen voucher number 024784. Leaves were washed, dried, and macerated. To prepare aqueous extracts, 5 grams of leaves powder were allowed to stand in boiling water $(80 \mathrm{ml})$ for 10 minutes, freeze dried (Freeze Dry Systems, Labconco Corporation, KC) and stored at $20^{\circ} \mathrm{C}$, until use. To produce methanol extracts, 5 grams of leaves powder were allowed to stand in $100 \%$ methanol ( $\left.80 \mathrm{ml}\right)$ for 24 hours at room temperature, solution was then dried in a Speed Vac (Milford.MA) and stored at $6^{\circ} \mathrm{C}$, until use. Aqueous and methanol extracts were then diluted to $1 \mathrm{mg} / \mathrm{ml}$ in sterile media. Under aseptic conditions, the products were then filtrated through $0.22 \mu$-pore size diameter filters (Whatman filters, Whatman International Ltd., Maidstone, England) and one milliliter aliquots were stored in $1.5 \mathrm{ml}$ Eppendorf tubes at $-20^{\circ}$.

\section{Plant extracts susceptibility testing}

In brief, $50 \mu \mathrm{l}$ of $H$. pylori suspensions at $2.5 \times 10^{5}$ bacteria/mL were plated in Brucella broth (Difco), in flat-bottomed 96-well plates (Corning Incorporated, Corning, NY), in the presence or absence of serial dilutions (1:2) of the G. glutinosum aqueous or methanol extract $(50 \mu \mathrm{l})$ at $1 \mathrm{mg} / \mathrm{ml}$, and $50 \mu \mathrm{l}$ antibiotic control (tetracycline), methanol vehicle control or culture medium. The methanol vehicle control was similarly processed as with plant methanol extractions, but without plant material. Plates were then incubated for $6 \mathrm{~h}$ at $37^{\circ} \mathrm{C}$, after which the tetrazolium salt MTT was added to all wells at a final concentration of $0.5 \mathrm{mg} / \mathrm{ml}$, and plates were incubated for 15 additional minutes. At the end of the incubation period, $80 \mu \mathrm{l}$ of DMSO were added to all wells and plates were incubated for 15 minutes. Optical densities resulting from dissolved formazan crystals were then read in a microplate reader (DTX 880 Multimode detector, Becton Dickinson, Austria) a 570 nm (Gomez-Flores et al., 2009, 2010; Caballero-Hernandez et al., 2009). In regard to CFUs determination, $50 \mu \mathrm{l}$ of the microbial suspensions were plated in Brucella broth, in flat-bottomed 96-well plates (Corning Incorporated), in the presence or absence of serial dilutions (1:2) of the G. glutinosum aqueous or methanol extract (50 $\mu \mathrm{l})$, antibiotic control (5 $\mu \mathrm{g} / \mathrm{ml}$ tetracycline), and vehicle controls (methanol and culture medium). Then, 1:10,000 dilutions were prepared from the wells and $100 \mu \mathrm{l}$ were plated on Brucella agar plates (Difco). Agar plates were then incubated at $37^{\circ} \mathrm{C}$ for $24 \mathrm{~h}$ and colonies were counted in a colony counter (ULB-100, Lightbox 37864-2000, Scienceware BEL-ART products, Pequannock, NJ). Percent growth inhibition was calculated as follows: 
Gomez et al., Afr J Tradit Complement Altern Med. (2016) 13(4):55-59

doi: $10.21010 /$ ajtcam.v13i4.9

$$
\% \text { Growth inhibition }=100-\frac{\mathrm{A}_{570} \text { or CFU/ml of cells treated with extract }}{\mathrm{A}_{570} \text { or } \mathrm{CFU} / \mathrm{ml} \text { untreated cells }} \times 100
$$

\section{Statistical analysis}

Data represent means \pm SEM of triplicate determinations from three independent experiments. Level of significance was assessed by the Student $t$ test and one-way ANOVA.

\section{Results}

G. glutinosum aqueous extract did not alter H. pylori growth (data not shown), however, methanol extract showed minimal inhibitory concentration (MIC) of $31.25 \mu \mathrm{g} / \mathrm{ml}$ and $250 \mu \mathrm{g} / \mathrm{ml}$ and induced a maximum of $82 \%$ and $100 \%$ growth inhibition against $H$. pylori, as measured by the MTT reduction assay and CFU method, respectively (Fig. 1). Methanol extract caused from $24 \%$ to $82 \%$ significant $(p<0.05) H$. pylori growth inhibition at concentrations from $31.25 \mu \mathrm{g} / \mathrm{ml}$ to $500 \mu \mathrm{g} / \mathrm{ml}$, respectively, as measured by the MTT reduction assay, and significant $(p<0.05) 52 \%$ and $100 \%$ growth inhibition at concentrations of $250 \mu \mathrm{g} / \mathrm{ml}$ and $500 \mu \mathrm{g} / \mathrm{ml}$, respectively, as measured by the CFU method (Fig. 1). Methanol vehicle control or medium alone did not alter bacterial growth (data not shown).

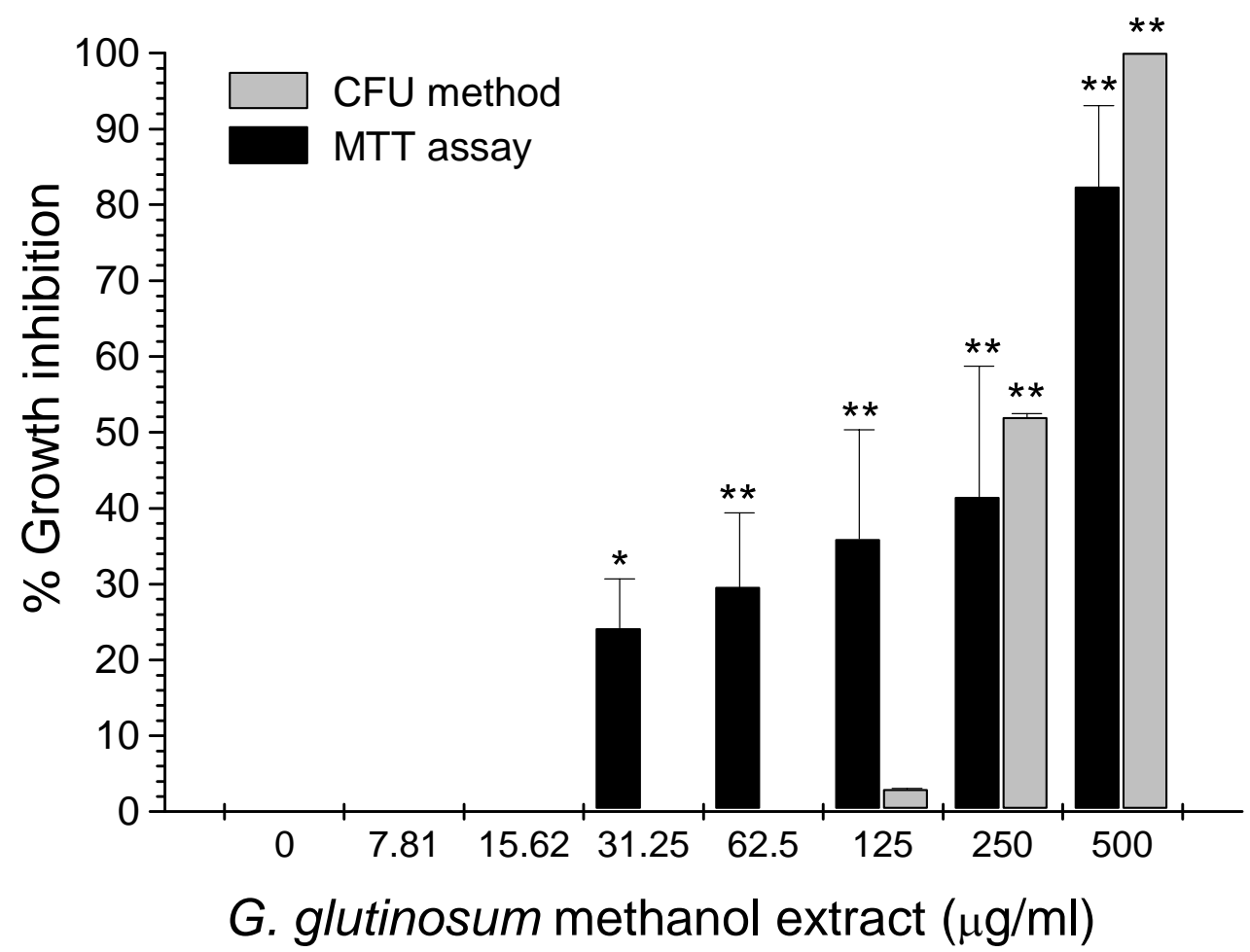

Figure 1: Antimicrobial effect of G. glutinosum methanol extract on $H$. pylori growth. $H$. pylori culture suspensions were incubated in the presence or absence of various concentrations of G. glutinosm methanol extract, after which growth was measured by the MTT reduction assay and CFU method, as explained in the text. Data represent means \pm SEM of triplicate determinations from three independent experiments. ${ }^{*} p<0.05$, $* * p<0.01$, compared with $G$. glutinosum extract-untreated control. Optical density at $570 \mathrm{~nm}$ for untreated cells was $0.85 \pm 0.03$ for the MTT reduction technique, whereas CFU control value for untreated cells was $3.5 \times 10^{8} \pm 8 \times 10^{6}$ $\mathrm{CFU} / \mathrm{ml}$. 


\section{doi: $10.21010 /$ ajtcam.v13i4.9 \\ Discussion}

Gomez et al., Afr J Tradit Complement Altern Med. (2016) 13(4):55-59

Medicinal plants have become popular worldwide because of their potential health benefits; these plants can be consumed or directly applied to treat infections (Rojas et al., 2006). Compounds synthesized by plants have great therapeutic potential due to their chemical constituents, for which the evaluation of their antimicrobial activity is important to develop alternative pharmacological products (Rodriguez-Fragoso et al., 2008).

There are studies with Asteraceae plant extracts as antibacterial agents, but none is related to their effects against $H$. pylori; the selection of G. glutinosum for the present study was based on its medicinal traditional use in Mexico. The use of aqueous and methanol plant extracts is common for this type of studies (Akihisa et al., 2005; Jiménez-Arellanes et al., 2003; Rai and Acharya, 1999).

Various biological activities of plants of the Asteraceae family including Baccharis gaudichaudiana (Guo et al., 2006), Anthemis aciphyla (Baser et al., 2006), Echinops ritro (Fokialakis et al.,2006), and Pterocaulon spp (Stein et al., 2006) have been reported. G. glutinosum hexane extracts were shown to possess antibacterial and antifungal activities (Canales et al., 2007). In the present study, $G$. glutinosum extract MICs against $H$. pylori ranged from $31.25 \mu \mathrm{g} / \mathrm{ml}$ to $250 \mu \mathrm{g} / \mathrm{ml}$. It is accepted that antimicrobial agents from plants have clinical potential if their MICs are in the range from 100 to $1000 \mu \mathrm{g} / \mathrm{ml}$ (Drusano, 2004); thus, the results of the present study may be an indication of an important antibiotic activity of $G$. glutinosum extracts against $H$. pylori.

Medicinal plants have proven to be important sources of antimicrobial agents, many of which have been the basis for the development of new pharmaceuticals drugs, which may overcome the increasing resistance of many pathogens to common antibiotics (Chinedium, 2005; Moreillon, 2000; Rusell, 2000).

\section{Conclusion}

To our knowledge, this is the first report showing that G. glutinosum methanol extracts inhibit H. pylori growth in-vitro. There are still a number of plant compounds that remain to be evaluated at the molecular, cellular, and physiological levels for their potential to treat human diseases.

\section{Acknowledgement}

This work was supported by the Programa de Apoyo a la Investigación Científica y Tecnológica (PAICyT) from Universidad Autónoma de Nuevo León to RGF.

\section{References}

1. Akihisa, T., Franzblau, S.G., Ukiya, M., Okuda, H., Zhang, F., Yasukawa, K., Suzuki, T. and Kimura, Y. (2005). Antitubercular activity of triterpenoids from Asteraceae flowers. Boil. Pharm. Bull. 28,158-160.

2. Arana, J.C. and Corona, A. (2009). Cancer Gástrico. Rev. Fac. Med. 47,204-209.

3. Baser, K.H.C., Demirci, B., Iscan, G., Hashimoto, T., Demirci, F., Noma, Y. and Asakawa, Y. (2006). The essential oil constituents and antimicrobial activity of Anthemis aciphylla BOISS. var. discoidea BOISS. Chem. Pharm. Bull. 54,222-225.

4. Borchers, A.T., Keen, C.L., Stern, J.S. and Gershwin, M.E. (2000). Inflammation and Native American medicine: the role of botanicals. Am. J. Clin. Nutr. 72,339-347.

5. Caballero-Hernández, D., Gomez-Flores, R., Tamez-Guerra, P., Tamez-Guerra, R. and Rodriguez-Padilla, C. (2009). Role of immunogenic fetuin A on L5178Y-R lympohoma tumorigenesis. Cancer Invest. 27,257-263.

6. Calderon, J.S., Segura-Correa, R., Cespedes, C.L. and Toscano, R.A. (2001). Crystal and molecular structure of (-)-17-hydroxy-neoclerod-3-en-15-oic acid from Gymnosperma glutinosum. Anal. Sci. 17,1467-1468.

7. Canales, M., Hernández, T., Serrano, R., Hernández, L.B., Duran, A., Ríos, V., Sigrist, S., Hernández, H.L., Garcia, A.M., AngelesLópez, O., Fernández-Araiza, M.A. and Avila, G. (2007). Antimicrobial and general toxicity activities of Gymnosperma glutinosum: a comparative study. J. Ethnopharmacol. 110,343-347.

8. Canales, M., Hernández, T., Caballero, J., Romo de Vivar, A., Avila, G., Duran, A. and Lira, R. (2005). Informant consensus factor and antibacterial activity of the medicinal plants used by the people of San Rafael Coxcatlán, Puebla, México. J. Ethnopharmacol. 97,429-439.

9. Chinedum, I.E. (2005). Microbial resistance to antibiotics. Afr. J. Biotechnol. 4,1606-1611.

10. Domínguez, X.A. and Torre, B. (1974). Two pentamethoxylated flavonoids from Gymnosperma glutinosum. Phytochemistry $13,1624-1625$.

11. Drusano, G.L. (2004). Antimicrobial pharmacodynamics: Critical interactions of "bug and drug". Nature Rev. 2,289-300.

12. Dunn, B.E., Cohen, H. and Blaser, M.J. (1997). Helicobacter pylori. Clin. Microbiol. Rev. 10,720-741.

13. Fokialakis, N., Cantrell, C.L., Duke, S.O., Skaltsounis, A.L. and Wedge, D.E. (2006). Antifungal activity of thioterpens from Echinops ritro. J. Agric. Food Chem. 54,1651-1655. 


\section{Gomez et al., Afr J Tradit Complement Altern Med. (2016) 13(4):55-59}

\section{doi: 10.21010/ajtcam.v13i4.9}

14. Garcia-Alvarado, J.S., Verde-Star, M.J. and Heredia-Rojas, N.L. (2001). Traditional uses and scientific knowledge of medicinal plants from Mexico and Central America. J. Herbs Spices Med. Plants 8,37-90.

15. Gomez-Flores, R., Hernández-Martínez, H., Tamez-Guerra, P., Tamez-Guerra, R., Quintanilla-Licea, R., Monreal-Cuevas, E. and Rodríguez-Padilla, C. (2010). Antitumor and immunomodulating potential of Coriandrum sativum, Piper nigrum and Cinnamomum zeylanicum. J. Nat. Prod. (India) 3,54-63.

16. Gomez-Flores, R., Verastegui-Rodriguez, L., Quintanilla-Licea, R.,Tamez-Guerra, P., Monreal-Cuevas, E., Tamez-Guerra, R. and Rodríguez-Padilla, C. (2009). Antitumor properties of Gymnosperma glutinosum leaf extracts. Cancer Invest. 27,149 - 155.

17. Gomez-Flores, R., Arzate-Quintana, C., R. Quintanilla-Licea, P. Tamez-Guerra, R. Tamez-Guerra, E. Monreal-Cuevas and C. Rodríguez-Padilla. 2008. Antimicrobial Activity of Persea Americana Mill (Lauraceae) (Avocado) and Gymnosperma glutinosum (Spreng.) Less (Asteraceae) Leaf Extracts and Active Fractions Against Mycobacterium tuberculosis. Am.-Eur. J. Sci. Res. 3,188194.

18. Guo, Y., Li, Y., Xu, J., Watanabe, R., Oshima, Y., Yamakuni, T. and Ohizumi, Y. (2006). Bioactive ent-clerodane diterpenoids from the aerial parts of Baccharis gaudichaudiana. J. Nat. Prod. 69,274-276.

19. Hoffman, J.S., Katz, L.M. and Cave, D.R. (1999). Efficacy of a 1 -week regimen of ranitidine bismuth citrate in combination with metronidazole and clarithromycin for Helicobacter pylori eradication. Aliment Pharmacol. Ther. 13,503-506.

20. Jimenez-Arellanes, A., Meckes, M., Ramirez, R., Torres, J. and Luna-Herrera, J. (2003). Activity against multidrug-resistant Mycobacterium tuberculosis in Mexican plants used to treat respiratory diseases. Phytother. Res. 17,903-908.

21. Maldonado, M., Segura-Carrera, R., Ortega, A., Calderón, J.S. and Fronczek, F.R. (1994). Ent-Labdane y Neo-Clerodore diterpenes from Gymnosperma glutinosum. Phytochemistry 35,721-724.

22. Martínez, M. (1989). Las Plantas Medicinales de México. Ediciones Botas, (México), p. 1-656.

23. Moreillon, P. (2000). Means of bacterial resistance. Rev. Med. Suisse Romande 120,641-50.

24. Quintanilla-Licea, R., Morado-Castillo, R., Gomez-Flores, R., Laatsch, H., Verde-Star, M.J., Hernández-Martínez, H., TamezGuerra, P., Tamez-Guerra, R. and Rodríguez-Padilla, C. (2012). Bioassay-guided isolation and identification of cytotoxic compounds from Gymnosperma glutinosum leaves. Molecules 17,11229-11241.

25. Rai, M.K. and Acharya, D. (1999). Screening of some Asteraceous plants for antimycotic activity. Comp. Newsl. 34,37-43.

26. Ramakrishnan, K. and Salinas, R.C. (2007). Peptic Ulcer Disease. Am. Fam. Physician. 76,1005-1012.

27. Rodriguez-Fragoso, L., Reyes-Esparza, J., Burchielb, S., Herrera-Ruiza, D., Torres, E. (2008). Risks and benefits of commonly used herbal medicines in Mexico. Toxicol. Appl. Pharmacol. 227,125-35.

28. Rojas, J.J., Ochoa, V.J., Ocampo, S.A. and Muñoz, J.F. (2006). Screening for antimicrobial activity of ten medicinal plants used in Colombian folkloric medicine: A possible alternative in the treatment of non-nosocomial infections. BMC Complement Altern. Med. 6,2.

29. Russell, A.D. (2000). Introduction of biocides into clinical practice and the impact on antibiotic-resistant bacteria. J. Appl. Microbiol. 92,121S-135S

30. Serrano, R., Hernández, T., Canales, M., García-Bores, A.M., Romo De Vivar, A., Céspedes, C.L. and Ávila, J.G. (2009). Entlabdane type diterpene with antifungal activity from Gymnosperma glutinosum (Spreng.) Less. (Asteraceae). Bol. Latinoam. Caribe Plant. Med. Aromaticas 8,412-418.

31. Stein, A.C., Alvarez, S., Avancini, C., Zacchino, S. and von-Poser, G. (2006). Antifungal activity of some coumarins obtained from species of Pterocaulon (Asteraceae). J. Ethnopharmacol. 107,95-98.

32. Torrado-Truiti, M.C., Sarragiotto, M.H., Abreu Filho, B.A., Vataru-Nakamura, C. and Dias Filho, B.P. (2003). In Vitro antibacterial activity of a 7-O-B-D-glucopyranosyl-nutanocoumarin from Chaptalia nutans (Asteraceae). Mem. Inst. Oswaldo Cruz 98,283-286. 